\title{
Evaluation of Various Methodologies Used in Purification of Biologically Active Carbohydrates Derived from Marine Life
}

\author{
Abdullah Faisal Aldairi* \\ Faculty of Applied Medical Sciences, Umm Al-Qura University, Saudi Arabia
}

*Corresponding author: Abdullah Faisal Aldairi, Faculty of Applied Medical Sciences, Umm Al-Qura University, Makkah, Saudi Arabia

\section{ARTICLE INFO}

Received: 幽 May 05, 2020

Published: 幽 May 13, 2020

Citation: Aldairi A. Evaluation of Various Methodologies Used in Purification of Biologically Active Carbohydrates Derived from Marine Life. Biomed J Sci \& Tech Res 27(4)-2020. BJSTR. MS.ID.004531.

Keywords: Glycosaminoglycan GAG; Marine Life; Biological Activity
Abstract

Although various biologically active drugs derived from natural products, especially marine life such as antiproliferation and antioxidant drugs have been launched. Biologically active carbohydrates purification field involves different purification methods. There are major issues with extraction and purification of glycosaminoglycan (GAG)-derived from marine life. Lack of standard method for GAGs purification from marine life has led to incomplete purification and it made the characterization step very challenging. There are three main purification methods used to purify GAGs from marine life, which are de-fat, proteolysis and chromatographic techniques. The main issue is that in each method there are several techniques used, thus, it would lead to poor GAGs purification as well as the biological activity could be lost, thus It would make GAG purification methods not reliable and it might be not reproduceable. This review concluded several methods used in GAGs purification in order to allow better understanding of different methods used in GAG purification.

Abbreviations: PG: Proteoglycans; DS: Dermatan Sulfate; KS: Keratan Sulfate; HA: Hyaluronan RER: Rough Endoplasmic Reticulum; EMA: European Medicines Agency; USFDA: United State Food and Drug Administration; SEC: Size-exclusion Chromatography

\section{Introduction}

Carbohydrates are molecules consisting mainly of three basic elements of carbon, oxygen and hydrogen with the empirical formula $\left(\mathrm{CH}_{2} \mathrm{O}\right)$. Carbohydrates can be classified according to its length into monosaccharides, oligosaccharides, and polysaccharides. Monosaccharides comprise the basic building blocks of carbohydrates. This type of carbohydrates is known as simple sugars; therefore, it cannot be hydrolysed into simpler forms of carbohydrates. Monosaccharides structure is based on the number of carbon atoms, for instance, three carbons monosaccharide is known as triose, four carbons (tetrose), five carbons (pentose) and six carbons (hexose). Monosaccharides can be classified into aldehydes or ketones, according to the carbonyl group. In addition, carbohydrates have a chiral carbon that can give monosaccharides their structural configuration. Chiral carbon is represented via dextro-rotary(D) or levo-rotary (L) isomers [1,2].
Oligosaccharides are shorter sugar polymers, typically consisting of two to about hundred monosaccharides, attached together via glyosidic linkages. Oligosaccharides can be found freely in the blood or it can be attached to proteins or lipids forming a special type of carbohydrates [2].

Polysaccharides consist of long chain of monosaccharides attached together via glyosidic linkages. It can be classified according to its chain length, basic building blocks, branching points and types of glycosidic linkages. According to the polysaccharides basic building blocks, it can be divided into homo- polysaccharides and hetero-polysaccharides. Homo-polysaccharides consists of one type of monosaccharides along the chain. However, hetero polysaccharide consists of more than one monosaccharide along the chain, for example, glycoconjugates such as heparan sulphate which consists of repeating glucosamine and uronic acid units [1]. 


\section{Glycoconjugate}

Glycoconjugate is a carbohydrate moiety that is covalently attached to a protein or lipid molecule. Carbohydrate which linked protein residues known as glycoproteins. There are subtype of glycoproteins known as proteoglycans (PG), which is composed of a particular amino-sugars known as glycosaminoglycan (GAG) attached to core protein residues [3]. GAGs are a group of long, unbranched hetero-polysaccharides consisting of repeated disaccharide units of uronic acid covalently attached to amino-sugar via glycosidic bonds. There are six types of GAGs in the literature, which are heparan sulfate (HS), heparin, chondroitin sulfate (CS), dermatan sulfate (DS), keratan sulfate (KS) and hyaluronan (HA) [1]. HS is composed of repeating disaccharide building block that is thought to be [GlcA $(1 \rightarrow 4) \mathrm{GlcNH}_{2}$ ]. Heparin is an intracellular type, which is composed of repeating disaccharide formula as [IdoA $(1 \rightarrow 4)$ GlcNH2]. CS common repeating disaccharide units are composed of [GlcA $(1 \rightarrow 3) \mathrm{GalNH}_{2}$ ]. DS basic disaccharide building block is composed of [IdoA $\left.(1 \rightarrow 3) G^{-} \mathrm{GalNH}_{2}\right]$. KS consists of a linear polymer of repeated disaccharides $[\rightarrow 3) \beta$-D-galactose $(1 \rightarrow 4) \beta$-DGlcNAc $(1 \rightarrow]$.

Finally, HA is considered as simple GAG-type, which is unbranched and unaltered GAG. Its basic repeating disaccharides is composed of GlcA (1 $\rightarrow 3)$ GlcNAc [4]. GAGs biosynthesis starts from the rough endoplasmic reticulum (RER), where core protein in synthesised, afterwards, thus core protein is transferred to Golgi, where protein glycosylation occurs. In Golgi, several monosaccharides catalysed from their precursor and attached to the core protein residues in a process known as protein glycosylation, resulting in N-linked or O-linked glycan. N-linked glycans occur when GAG monosaccharides attached to asparagine (Asn) residue withing core protein residues. On the other hand, O-linked glycans occur when GAGs monosaccharides attach to serine (Ser)or threonine (Thr) residues of the core protein [1,57]. GAGs structures are very diverse, and their synthesis is not template driven, like that of other biomolecules. All these structural modifications give GAGs their structural heterogeneity and wide range of biological functions. GAGs structural heterogeneity can lead to several cellular and extracellular functions, which depend on GAG types and the cell type that would vary from simple cellular function to cellular morphogenesis [8].

\section{GAGs Derived from Marine Life as A Potential Pharmaceutical Agent}

Recently, there has been increase demand for development of new drugs from natural products such as bacteria, animals including marine life. Marine life has derived several pharmaceutical utilities as therapeutic agent [9]. One of the largest phylain the animal kingdom known as molluscs, including snails, bivalves, squid and others. Various molluscs were used for dietary intake, as it has excellent dietary benefits. Over the past several years, there has been an increased demand for developing new anti-cancer agents derived from natural products such as plants, bacteria and animals, including marine life. The main advantage of natural product-derived anticancer drugs that it would have acceptable side-effects than of other chemically synthetic drugs [10]. There are several drugs either approved by the United State Food and Drug Administration (US-FDA), European Medicines Agency (EMA) orin clinical trial that have been derived from marine sources. For instance, Cytarabin that was the first marine-derived chemotherapeutic drug isolated from a sponge (Tethya crypta) [11]. Dolastatin which is a polypeptide product from marine mollusc (Dolabellaauricularia) can inhibit microtubule assembly as well astubulin polymerization, resulting in cell apoptosis. Although it was not successfully approved, this drug progressed to advanced phases in clinical trials, and its derivatives are still being considered as anticancer candidate $[12,13]$.

Halichondrin is a tubulin inhibitor agent, which was isolated from Japanese sponge (Halichondria okadai), is synthetic macrocyclic ketone with enhanced antitumor activities against breast cancer. The US-FDA has approved its synthetic analogue since 2010 [14]. Cyclic-peptide drug Kahalalide-F was isolated from the mollusc (Elysiarubefescens) has anti-lysosomal properties. Ithasentered phase-I clinicalt rials against prostate cancer and phase-II against hepatocellular carcinoma, non-small cell lung cancer and melanoma [15,16]. Didemnin-B isolated from (Carribean tunicate) shows inhibition of DNA-synthase that leads to cell cycle arrest [17]. Many molluscs have been used for dietary intake, as they have great nutritional benefits. Traditionally, molluscs have been used as natural treatments in Chinese traditional medicine; therefore, there has been great interest in investigating their valuable elements to be used as pharmaceutical resources [18]. The high content of uncommon polysaccharides structures in marine organisms make them a favourable candidate of natural products with various pharmaceutical benefits, including in cancer therapy. Generally, mollusc soft-body structural investigations have revealed high amounts of carbohydrates with some proteins and lipids, which makes carbohydrates a major area of interest from a pharmaceutical perspective [19].

Polysaccharides from vertebrates and invertebrates have emerged as powerful platforms for medical utilities, as they have various biological activities such as immunostimulatory, antioxidant, and antitumor activities [9,20,21]. Polysaccharides isolated from invertebrates have shown very different structures to common mammalian polysaccharides in terms of monosaccharide composition, molecular weight, degree of sulphation, type of glycosidic linkages, and branching points. For instance, a novel polysaccharide isolated from the head of ashrimph as a novel combination structure between heparin and HS known as a hybrid hep/HS structure [22]. This structural diversity in polysaccharides has generated additional features for the senovel molecules that could make them potent tool singlecobiology, especially as pharmaceutical agents [9]. Although there are several studies of 
marine life as source of promising biologically active substances that can be used as pharmaceutical target for various disorders such as cancer, however, various purification techniques were used to purify biologically active GAG and using different structural analysis techniques to characterize this active compound made this field of carbohydrates challenging. These major issues in biologically active GAGs from marine life including, extraction procedure, purification step and characterisation technique, which has created a wide gap on the final structure for GAGs to be used as pharmaceutical agent.

There is no standard method to extract GAGs from in marine life to purified active compounds. GAGs extraction and purification methods from marine source mainly follow three consecutive steps, namely, de-shell (shell removal), de-fat (lipid removal) and proteolysis. However, there are inconsistency in GAG extraction techniques. Indeed, the nature of the GAG polysaccharide derived from marine source, which has an unknown structure and lacks any chromophore that affects adopting an appropriate purification step. For instance, size-exclusion chromatography requires a well-known molecular weight sample, and lectin affinity chromatography requires a particular ligand to allow the complex to interact. This lack of standardization has assigned as major issues in GAGs purification from marine life. Therefore, GAGs with potent biological activity, for instance, antiproliferative or anticoagulant activity were not assigned as pure polysaccharide, but it could be identified as proteoglycan, as other biomolecules could play a role in the biological function. The aim of this review is to evaluate different methodologies used to extract and purify GAG-derived from marine life with potent biological activities.

\section{Purification Methods of GAG-Derived from Marine} Life

The literature has demonstrated several purification techniques to obtain purified GAGs from different marine life species. Firstly, de-fat technique, which considered as the first step in GAGs purification. Next, proteolysis technique which is used to ensure removing on $\mathrm{N}$-linked or $\mathrm{O}$-linked proteins that is attached to the polysaccharides chain. Finally, using various chromatographic methods in order to obtain GAG purified chain.

\section{GAG-Defat Techniques}

The Defat process is the first step of the purification, which ensure removing the lipid-soluble molecules by using different solvents such as acetone. The procedure begins to remove the shell and submerge the soft body in de-fat solvents. The literature has demonstrated several types of solvents used, different incubation period and temperature used to remove lipid-soluble molecules.

De-Fat Method Using Acetone: Acetone was used as dehydrating agent, which used to achieve complete lipid removal from polysaccharide chain. Although acetone was used, different techniques were observed to remove lipids including different incubation time and temperatures (Table 1) (23-35).

Table 1: Shows different techniques used to remove lipid-soluble molecules using acetone.

\begin{tabular}{|c|c|c|}
\hline Species & Defat Process Using Acetone & Reference \\
\hline Mollusc Gastropods (Achatina fulica) & $\begin{array}{c}\text { The whole soft body was merged in fresh acetoneevery } 24 \text { hours } \\
\text { over three days at } 4^{\circ} \mathrm{C} .\end{array}$ & {$[23]$} \\
\hline Bivalve mollusc (Cerastoderma edule) & & [9] \\
\hline Bivalve Whelk (Buccinum undatum) & & {$[21]$} \\
\hline Chordata Tunicata (Styela plicata) & $\begin{array}{l}\text { The whole soft body was cut into small pieces then merged in } \\
\text { acetone for } 24 \mathrm{~h} \text { at } 4^{\circ} \mathrm{C} \text {. }\end{array}$ & {$[24]$} \\
\hline Bivalve Mollusc (Nodipecten nodosus) & Whole-body tissue defatted using acetone for $24 \mathrm{~h}$ at $60^{\circ} \mathrm{C}$. & {$[25]$} \\
\hline Bivalve Mollusc (Amusium pleuronectes) & & [26] \\
\hline Chordata Chondrichthyes (Aetobatus narinari) & & [27] \\
\hline Bivalve Mollusc (Scapharca inaequivalvis) & & {$[28]$} \\
\hline Bivalve Mollusc (Mytilus galloprovincialis) & & [29] \\
\hline Fish (Monkfish, codfish, spiny dogfish, salmon and tuna) & & {$[30]$} \\
\hline Fish (Salmo salar) & Fish skin was defatted in acetone for $48 \mathrm{~h}$. & {$[31]$} \\
\hline $\begin{array}{l}\text { Chordata Chondrichthyes (Isurus oxyrinchus and Prionace } \\
\text { glauca) }\end{array}$ & Sample was homogenized with acetone and incubated overnight & {$[32]$} \\
\hline Mollusc(Enteroctopus dofleini) & & [33] \\
\hline $\begin{array}{c}\text { Bivalve Molluscs (Ruditapes philippinarum, Scapharca } \\
\text { broughtonii, Mizuhopecten yessoensis, Turbo cornutus, } \\
\text { Crassostrea nippona, Corbicula japonica, Mytilus } \\
\text { galloprovincialis, Neptunea intersculpta, Pseudocardium } \\
\text { sachalinense and Crassostrea gigas) }\end{array}$ & & {$[34]$} \\
\hline Bivalve Mollusc (Mactra chinensis) & $\begin{array}{l}\text { Sample was homogenised in acetone } \mathrm{X} 3 \text { times, each time acetone } \\
\text { was removed using centrifugation at room temperature. }\end{array}$ & {$[35]$} \\
\hline Bivalve Mollusc (Tapes phylippinarum) & $\begin{array}{l}\text { Soft body was merged in acetone, then filtered and dried for } 24 \\
\text { h. }\end{array}$ & {$[18]$} \\
\hline
\end{tabular}


De-Fat Method Using Sodium Sulfate $\left(\mathrm{Na}_{2} \mathrm{SO}_{4}\right)$ : The second def-at method was performed using $\mathrm{Na}_{2} \mathrm{SO}_{4}$ as a dehydrating agent (Table 2) (36,37).

Table 2: Shows method used $\mathrm{Na}_{2} \mathrm{SO}_{4}$ as dehydrating agent, which used as a potential step in removing lipid-soluble molecules from sample.

\begin{tabular}{|c|c|c|}
\hline Species & De-fat Process Using Na2SO4 & Reference \\
\hline Bivalve Mollusc (Katelysia opima) & $\begin{array}{l}\text { Body tissue was homogenized with } \mathrm{Na}_{2} \mathrm{SO}_{4} \mathrm{pH} 11.5 \text {, at } 55^{\circ} \mathrm{C} \text { for } \\
\qquad 90 \mathrm{~min} .\end{array}$ & {$[36]$} \\
\hline Bivalve Mollusc (B. spirata and p.glaucum) & & [37] \\
\hline
\end{tabular}

De-Fat Method Using Chloroform/Methanol: One of the most versatile and effective lipid extraction procedures. Briefly, this procedure uses a one-phase alcoholic solvent system, namely chloroform-methanol-water $(1: 2: 0.8 \mathrm{v} / \mathrm{v})$ that rapidly and efficiently extracts the lipids. The extract is then diluted with one volume each of chloroform and water to form the two phased system, chloroform and methanol-water. Any water-soluble contents are thus readily partitioned into the methanol-water, leaving the lipids relatively free of contaminants in the chloroform phase $[38,39]$ (Table 3).

Table 3: Shows method used Chloroform/Methanol as dehydrating agent, which used as a potential step in removing lipid-soluble molecules.

\begin{tabular}{|c|c|c|}
\hline Species & De-Fat Process Using Chloroform/Methanol & Reference \\
\hline Sea Cucumber (Stichopus Japonicus) & $\begin{array}{c}\text { The soft body was homogenized with chloroform/methanol, then, filtered to } \\
\text { ensure fat removal }\end{array}$ & [39] \\
\hline
\end{tabular}

De-Fat Method Using Acetone and Ethanol: According to this method, lipid-soluble molecules were removed by the action of acetone and ethanol. Acetone will remove lipid-soluble molecules; while ethanol was used to enhance the dehydration process (Table 4) [40].

Table 4: Shows GAG d-fat technique using acetone and ethanol as solvents.

\begin{tabular}{|c|c|c|}
\hline Species & De-Fat Using Chloroform/Methanol \\
\hline Seagrass (Phanerogam Zostera marina) & $\begin{array}{c}\text { The sample was submerged in acetone overnight, then, washed with } \\
\text { acetone and ethanol, until the supernatant become clear. }\end{array}$ \\
\hline [40]
\end{tabular}

De-fat Method Using Ethanol (Table 5)[41]

Table 5: Shows GAG d-fat technique using ethanol as dehydrating solvents.

\begin{tabular}{|c|c|}
\hline Species & De-Fat Using Ethanol \\
\hline Chordata Chondrichthyes (Dasyatis kuhlii) & $\begin{array}{c}\text { The sample was cut into small pieces and soaked in ethanol for 7-days } \\
\text { to ensure full removal of lipids. }\end{array}$ \\
\hline
\end{tabular}

\section{GAG-Proteolysis Techniques}

This is the second step in GAG purification process, after defat, which lead to cleave GAG chain from the attached protein chain. This process mainly concerns about cleaving the polysaccharide chain, thaerefore, protein residues were hydrolysed either via enzymatic or chemical techniques. Enzymatic extraction, which mean removing of proteins by using enzymes, for instance, alcalase, papain or pronase [42]. On the other hand, chemical extraction by using different chemical such as Aluminium sulfate [36]. The following literature distinguished different techniques to remove protein residues using different concentrations, centrifugation, incubation period and temperatures.

Proteolysis Technique Using Papain Enzyme: Papain is a proteolytic enzyme derived from Papaya (Carica papaya) It was used to remove protein residues. Different proteolysis techniques were applied using papain as proteolytic enzyme (Table 6) $[43,44]$.

Table 6: Demonstrate various methodologies used papain as proteolytic agent. Different sample, enzyme concentration, buffers concentration and incubation periods were noticed.

\begin{tabular}{|c|c|c|}
\hline Species & Proteolysis Techniques Using Papain Enzyme \\
\hline Bivalve Mollusc (Mytilus galloprovincialis) & $\begin{array}{c}\text { Reference } \\
5.5 \text { containing }(5 \mathrm{mM} \text { EDTA and } 5 \mathrm{mM} \text { cysteine). 240 mg of papain was added to the } \\
\text { buffer containing dried materials and incubated for } 24 \mathrm{~h} \text { at } 60^{\circ} \mathrm{C} .\end{array}$ \\
\hline Bivalve Mollusc (Tapes phylippinarum) & $\begin{array}{c}14 \mathrm{~g} \text { was dissolved in } 280 \mathrm{~mL} \text { in } 100 \mathrm{mM} \text { Sodium acetate, } 5 \mathrm{mM} \text { ethylenediamine } \\
\text { acetic acid and } 5 \mathrm{mM} \text { cysteine pH } 5.5 .1 \mathrm{mg} \text { papain } / 1 \mathrm{~g} \text { of the dried materials was } \\
\text { mixed and incubated for } 24 \mathrm{~h} \text { at } 60^{\circ} \mathrm{C}\end{array}$ \\
\hline
\end{tabular}




\begin{tabular}{|c|c|c|}
\hline Bivalve Mollusc (Scapharca inaequivalvis) & $\begin{array}{l}\text { The dried body was dissolved in }(1 \mathrm{~g} / 20 \mathrm{~mL}) 0.1 \mathrm{M} \text { sodium acetate buffer } \mathrm{pH} 5.5 \text {, } \\
\text { then, } 1 \mathrm{mg} \text { papain } / 1 \mathrm{~g} \text { of the dried materials were mixed and incubated for } 24 \mathrm{~h} \text { at } 60 \\
{ }^{\circ} \mathrm{C}\end{array}$ & [28] \\
\hline Bivalve Mollusc (Nodipecten nodosus) & $\begin{array}{l}25 \mathrm{~g} \text { of dried materials were dissolved in } 500 \mathrm{~mL}(0.1 \mathrm{M} \text { sodium acetate) buffer (pH } \\
5.5) \text { with } 5 \mathrm{~g} \text { of papain in } 5 \mathrm{mM} \text { EDTA, and } 5 \mathrm{mM} \text { cysteine. Mixture was incubated } \\
\text { overnight at } 60^{\circ} \mathrm{C} \text {. After incubation period, the mixture was centrifuged } 2000 \times \mathrm{g} \text { for } \\
10 \mathrm{~min} \text {. This proteolysis method was been repeated three times }\end{array}$ & [25] \\
\hline Chordata Chondrichthyes (Raja clavate) & $\begin{array}{l}\text { Proteolysis method were dependent on dissolving the } 5 \mathrm{~g} \text { of Raja clavata on alcohol, } \\
\text { then added } 250 \mathrm{~mL} \text { of }(0.1 \mathrm{M} \text { sodium acetate buffer, EDTA } 5 \mathrm{mM} \text {, cystein } 5 \mathrm{mM} \mathrm{pH} \text { 6). } \\
\text { Afterwards, immediately added } 510 \mathrm{mg} \text { of papain. The mixture was incubated for } 24 \\
\text { hours at } 60^{\circ} \mathrm{C} \text {, then filtered with } 138 \mathrm{~mL} \text { of distilled water. }\end{array}$ & [44] \\
\hline Bivalve Mollusc (Amussium pleuronectus) & $\begin{array}{l}5 \mathrm{~g} \text { of defatted tissue in } 100 \mathrm{ml}(100 \mathrm{mM} \text { sodium acetate, } 5 \mathrm{mM} \text { EDTA and cysteine } \\
\mathrm{pH} 5.5) \text { and } 100 \mathrm{mg} \text { of papain/1 } \mathrm{g} \text { of defatted tissues was added and the buffer. The } \\
\text { mixture was incubated at } 60^{\circ} \mathrm{C} \text { for } 24 \mathrm{~h} .\end{array}$ & [26] \\
\hline $\begin{array}{l}\text { Chordata Chondrichthyes (Aetobatus } \\
\text { narinari) }\end{array}$ & & [27] \\
\hline Fish (Salmo salar) & & [31] \\
\hline Chordata Tunicata (Styela plicata) & & [24] \\
\hline $\begin{array}{l}\text { Fish (Monkfish, codfish, spiny dogfish, } \\
\text { salmon and tuna) }\end{array}$ & $\begin{array}{l}1 \mathrm{~g} \text { of defatted tissue was dissolved in } 10 \mathrm{~mL} \text { ( } 100 \mathrm{mM} \text { sodium acetate containing } \\
5 \mathrm{mM} \text { EDTA and } 5 \mathrm{mM} \text { cysteine buffer } \mathrm{pH} 5.5 \text { ). Then, added } 60 \mathrm{mg} \text { of papain to the } \\
\text { mixture. The mixture was incubated at } 60^{\circ} \mathrm{C} \text { for } 24 \mathrm{~h}\end{array}$ & [30] \\
\hline
\end{tabular}

Proteolysis Technique Using Alcalase Enzyme: Is a serine endopeptidase that is suitable for the hydrolysis of proteins. It has previously been used to produce soluble hydrolysates that digest the protein in the defatted tissues (Table 7) $[45,46,47]$.

Table 7: Shows various proteolysis techniques using alcalase enzyme to cleave GAGs that's attached via O-linages to protein residues via serine/threonine.

\begin{tabular}{|c|c|c|}
\hline Species & Proteolysis Technique Using Alcalase Enzyme & Reference \\
\hline Mollusc Gastropods (Achatina fulica) & $\begin{array}{c}\text { The sample was suspended in } 40 \mathrm{ml} \text { of } 0.05 \mathrm{M} \text { sodium carbonate buffer } \\
\mathrm{pH} 9.2), \text { then, incubated for } 48 \mathrm{~h} \text { at } 200 \mathrm{rpm} \text { at } 60^{\circ} \mathrm{C} \text { after adding } 2 \mathrm{ml} \\
\text { of alcalase enzyme }(2.4 \text { Anson units/g). }\end{array}$ & {$[23]$} \\
\hline Mollusc (Cerastoderma edule) & {$[9]$} & {$[21]$} \\
\hline Mollusc (Buccinum undatum) & & $\begin{array}{c}\text { [lcalase enzyme }(1: 100) \text { was added to the dried tissue, which dissolved } \\
\text { in water, then, and the mixture was incubated overnight at } 60^{\circ} \mathrm{C} .\end{array}$ \\
\hline Chordata Actinopterygii (Cyclopterus lumpus) & {$[47]$} \\
\hline
\end{tabular}

Proteolysis Technique Using Actinase-E Enzyme: Actinase-E is a protease that is derived from Streptomyces griseus, it is has mixture of three proteolytic activities containing serine protease (Table 8) [48].

Table 8: Shows different techniques used actinase-E enzyme to cleave protein residues from GAG chain.

\begin{tabular}{|c|c|c|}
\hline Species & Proteolysis Techniques Using Actinase-E & Reference \\
\hline Bivalve Mollusc (Mactra chinensis) & $\begin{array}{l}30 \mathrm{~g} \text { of dried tissue was dissolved in } 120 \mathrm{~mL} \text { of Tris-acetatebuffer } \mathrm{pH} \\
8.0) \text { containing actinase-E, then, the mixture was incubated for } 18 \mathrm{~h} \text { at } \\
45^{\circ} \mathrm{C} \text {. Afterwards, } 600 \mathrm{~mL} \text { of } \mathrm{NaOH} \text { buffer was added and the mixture } \\
\text { was cooled at } 4^{\circ} \mathrm{C} \text { for } 18 \mathrm{~h} \text {. }\end{array}$ & {$[35]$} \\
\hline Fish maw & $\begin{array}{l}2 \mathrm{~g} \text { of dried fish was homogenized in } 100 \mathrm{~mL} \text { distilled water,then, } 10 \\
\mathrm{mg} / \mathrm{mL} \text { actinase-E was added. The mixture was incubated at } 55^{\circ} \mathrm{C} \text { for } \\
48 \mathrm{~h} \text {, then, the mixture was centrifuged at } 4000 \mathrm{xg} \text { for } 30 \mathrm{~min} .\end{array}$ & [48] \\
\hline $\begin{array}{c}\text { Bivalve Mollusc (Ruditapes philippinarum, Scapharca } \\
\text { broughtonii, Mizuhopecten yessoensis, Turbo cornutus, } \\
\text { Crassostrea nippona, Corbicula japonica, Mytilus } \\
\text { galloprovincialis, Neptunea intersculpta, Pseudocardium } \\
\text { sachalinense and Crassostrea gigas) }\end{array}$ & $\begin{array}{l}10 \mathrm{mg} \text { of actinase-E g of dry powder was dissolved in } 50 \mathrm{mM} \text { Tris- } \\
\text { acetate (pH 8.0), then, the mixture was incubated for } 48 \mathrm{~h} \text { at } 45^{\circ} \mathrm{C} . \\
\text { Afterwards, the sample was further treated with a solution containing } \\
0.5 \mathrm{M} \mathrm{NaOH} \text { and } 0.3 \mathrm{M} \text { sodium borohydride }(20 \mathrm{~mL} / \mathrm{g} \text { of dried powder }) \text {, } \\
\text { the mixture was incubated at } 4^{\circ} \mathrm{C} \text { for overnight. Finally, proteins were } \\
\text { removed by centrifugation at } 1000 \mathrm{x} \text { g for } 30 \mathrm{~min} .\end{array}$ & [34] \\
\hline
\end{tabular}

Proteolysis Technique Using Pectinase Enzyme: Pectinase enzyme derived from Aspergillus niger, which is used to purify pectins molecules from the sample (Table 9). 
Table 9: Proactinase enzyme was used to cleave pectin polysaccharides chain from residual proteins.

\begin{tabular}{|c|c|c|}
\hline Species & Proteolysis Technique Using Pectinase Enzyme & Reference \\
\hline & $\begin{array}{c}1 \mathrm{~g} \text { of defatted tissue was dissolved in distilled water, then, pectinase } \\
\text { enzymes }(0.2 \% \mathrm{v} / \mathrm{v}) \text { was added. The mixture was incubated for } 1 \mathrm{~h} \text { at }\end{array}$ & {$\left[\begin{array}{l}3{ }^{\circ} \mathrm{C} \text {. Proteins were removed by centrifugation }(5000 \times \mathrm{g} \text { for } 15 \mathrm{~min}) . \\
\hline \text { Seagrass (Zostera marina) }\end{array}\right.$} \\
\hline
\end{tabular}

Aluminium Sulfate $\left[\mathbf{A l}_{2}\left(\mathbf{S O}_{4}\right)_{3}\right]$ : In this method, chemical hydrolysis of proteins residues from GAG chain (Table 10).

Table 10: Demonstrated the use of $\left[\mathrm{Al}_{2}\left(\mathrm{SO}_{4}\right)_{3}\right]$ as proteolysis technique.

\begin{tabular}{|c|c|c|}
\hline Species & Proteolysis Technique Using $\left[\mathrm{Al}_{2}\left(\mathrm{SO}_{4}\right)_{3}\right]$ & Reference \\
\hline Bivalve Mollusc (Katelysia opima) & $\begin{array}{c}\text { For proteolysis, } 80 \mathrm{mg} \text { of }\left[\mathrm{Al}_{2}\left(\mathrm{SO}_{4}\right)_{3}\right] \text { was added per kg of tissues and the } \\
\text { mixture was incubated for } 1 \mathrm{~h} \text { at } 95^{\circ} \mathrm{C}\end{array}$ & {$[36]$} \\
\hline $\begin{array}{c}\text { Mollusc Gastropods (Babylonia spirata and Phalium } \\
\text { glaucum) }\end{array}$ & & {$[37]$} \\
\hline
\end{tabular}

Urea and Sodium hydroxide ( $\mathrm{NaOH})$ : Urea was used aid protein denaturing process, in addition, NaOH was used to hydrolyse GAGs polysaccharides, which result in monosaccharides or oligosaccharides (Table 11).

Table 11: Sows the use of urea and $\mathrm{NaOH}$ in GAG purification.

\begin{tabular}{|c|c|c|}
\hline Species & Proteolysis Technique Using Urea and NaOH & Reference \\
\hline Chordata Chondrichthyes (Dasyatis kuhlii) & $\begin{array}{c}\text { Sample wad defatted, then, mixed with urea and sodium hydroxide in } \\
\text { order to denature protein as well as to degrade GAG chain. }\end{array}$ & [41] \\
\hline
\end{tabular}

\section{GAG Purification Using Various Chromatographic Techniques}

The aim of this process is to purify the biologically active components that is derived from polysaccharides, especially GAGs. The purification techniques were mostly used chromatographic techniques to purify GAGs according to their charge or size structure.

\section{GAG Purification Using Anion-Exchange Chromatography:} Anion-exchange chromatography was one of the most common methods for GAGs purification and fractionation. As GAGs known to carry highly negatively charged molecules such as heparin Penta saccharide structure [49]. Therefore, various purification techniques were particularly based on this feature. Anion-exchange resins were used with various solvents such as high molar $\mathrm{NaCl}$ solution in order to exchange the biologically active molecules.

Quaternary Aminoethyl (QAE)-Sephadex: QAE functional group is used as strong anion-exchanger. In this method, QAE functional group is attached to the sephadex resin, which is composed of cross-linked dextran with epichlorohydrin, to allow separation of negatively charged molecules (Table 12) [50].

Table 12: Shows different chromatographic techniques using QAE as anion-exchange resin, which purify GAGs according to their negatively charge.

\begin{tabular}{|c|c|c|}
\hline Species & Chromatographic Techniques Using QAE- Sephadex Resin & Reference \\
\hline $\begin{array}{l}\text { Monkfish, cod, spiny dogfish, } \\
\text { salmon and tuna }\end{array}$ & $\begin{array}{l}\text { The process used a column }(2 \times 40 \mathrm{~cm}) \text { packed with QAE Sephadex }(\mathrm{A}-25) \text { anion-exchange } \\
\text { resin. GAGs were eluted with a linear gradient of } \mathrm{NaCl} \text { from } 0.05-1.2 \mathrm{M} \text { over } 150 \mathrm{~min} \text { at flow } \\
\text { rate } 1 \mathrm{~mL} / \mathrm{min}\end{array}$ & [30] \\
\hline Clam (Tapes phylippinarum) & & [18] \\
\hline Scapharca inaequivalvis & & [28] \\
\hline Mytilus galloprovincialis & $\begin{array}{l}\text { The sample was applied to QAD Sephadex A-25 }(1 \mathrm{~cm} \times 20 \mathrm{~cm}) \text { column. GAGs were eluted } \\
\text { using a linear gradient of } \mathrm{NaCl} \text { from } 0.05-1.2 \mathrm{M} \text { over } 150 \mathrm{~min} \text { at flow rate } 1 \mathrm{~mL} / \mathrm{min}\end{array}$ & [29] \\
\hline
\end{tabular}

Diethylaminoethyl (DEAE)-Sepharose: DEAE is used as weak anion exchanger. In this method, DEAE is attached to Sepharose resin, which is composed of $6 \%$ cross-linked agarose (Table 13) [42].

Table 13: Shows different chromatographic techniques using DEAE-Sepharose as anion-exchange resin.

\begin{tabular}{|c|c|c|}
\hline Species & Chromatographic Techniques Using DEAE-Sephrose Resin & Reference \\
\hline Mactra chinensis & $\begin{array}{l}\text { Crude GAG sample was dissolved in distilled water, then applied to DEAE-sepharose fast flow } \\
\text { column. GAGs were eluted using gradient elution of two buffers, which are } 50 \mathrm{mM} \text { sodium } \\
\text { phosphate (pH 6) as buffer (A), and } 2.0 \mathrm{M} \mathrm{NaCl} \mathrm{in} 50 \mathrm{mM} \text { sodium phosphate (pH 6) as buffer } \\
\text { (B) at flow rate } 2 \mathrm{~mL} / \mathrm{min} \text { over } 180 \mathrm{~min} \text {. }\end{array}$ & [35] \\
\hline $\begin{array}{c}\text { Marine mollusc (Cerastoderma } \\
\text { edule) }\end{array}$ & $\begin{array}{l}\text { Crude GAG sample was dissolved in distilled water. Then applied to anion exchange column } \\
\text { (16 X } 200 \mathrm{~mm}) \text {, which packed with } 10 \mathrm{~mL} \text { of DEAE-Sepharose fast flow. GAGs were eluted } \\
\text { using a linear gradient }(0-1.5 \mathrm{M}) \mathrm{NaCl} \text { over } 70 \text { min. Elution was monitored using UV } 280 \mathrm{~nm}\end{array}$ & [9] \\
\hline
\end{tabular}


DEAE-Cellulose: In this methods, DEAE anion exchanger is attached to the cellulose resin (Table 14) [51].

Table 14: Shows different chromatographic techniques using DEAE-cellulose as anion-exchange resin.

\begin{tabular}{|c|c|c|}
\hline Species & Chromatographic Techniques Using DEAE- Cellulose Resin & References \\
\hline Bivalve (Katelysia opima) & $\begin{array}{l}\text { Crude GAG sample was purified using DEAE cellulose resin. GAGs elution was } \\
\text { achieved using } 1 \mathrm{M} \text { and } 2 \mathrm{M} \mathrm{NaCl} \text { buffer at flow rate } 12 \mathrm{~mL} / \mathrm{h} \text {. }\end{array}$ & {$[36]$} \\
\hline Marine bivalve mollusc (Amussium pleuronectus) & $\begin{array}{l}\text { Crude GAG sample was purified using DEAE cellulose A- } 25 \text { resin. GAGs were } \\
\text { eluted using a linear gradient of } \mathrm{NaCl} \mathrm{buffer}(0.05-1.2 \mathrm{M}) \text { at the flow rate of } \\
\qquad 1 \mathrm{~mL} / \mathrm{min} \text {. }\end{array}$ & [26] \\
\hline Liver of marine stingray (Aetobatus narinari) & & [27] \\
\hline Marine shrimp (litopenaeus vannamei) & $\begin{array}{l}\text { Crude GAG sample was purified using DEAE-Sephacel. GAGs were eluted } \\
\text { using a linear gradient of NaCl buffer of 0.5-1 M. Elution was monitored } \\
\text { using UV/VIS } 525 \mathrm{~nm}\end{array}$ & [51] \\
\hline
\end{tabular}

\section{Size-exclusion Chromatography (SEC)}

This method depends on molecules size, as SEC purifies molecules according to their molecular size. Sephadex is a gel that contains dextran with epichlorohydrin, where G-100 refer to a particular property of Sephadex as G-100 has fractionation range 4000-15000 kDa (Table 15).

Table 15: Shows different chromatographic techniques using SEC to purify GAGs according to chain size.

\begin{tabular}{|c|c|}
\hline Species & Chromatographic Techniques Using SEC Column \\
\hline Raja radula Raja clavata & $\begin{array}{c}\text { GAGs sample was applied to sephadex G-100 column (2.5 X 70 } \mathrm{cm}) \\
\text { using }(0.05 \mathrm{M}) \text { sodium acetate as elution buffer at flow rate } 10 \mathrm{~mL} / \mathrm{h} . \\
\text { Elution was monitored using UV } 215 \mathrm{~nm} .\end{array}$ \\
\hline
\end{tabular}

\section{Conclusion}

In conclusion, GAGs have wide range of structural diversity as well as biological activity, therefore, setting up a standard method in GAG purification would be result in highly purified biologically active compound from GAGs, which can be used as pharmaceutical agent. As conducted in this review, there are three main steps are used in purification of GAG-derived from marine life, which are de-fat, proteolysisand polysaccharide chain purification, however, various techniques were used in each method that resulted in lack of standard method in GAG purification. Hence, it is highly recommended to adapt versatile standard method to allow better purification of biologically active molecules derived from GAGs. Thus, it would be possible by evaluating the current purification techniques used in GAGs analysis and assign a gold standard method on purification techniques.

\section{Conflict of Interest}

The authors declare that there is no conflict of interest statement.

\section{References}

1. Nelson DL, Lehninger AL, Cox MM (2008) Lehninger principles of biochemistry. Macmillan.

2. Aïtcin PC, Flatt RJ (2015) Science and technology of concrete admixtures. Woodhead Publishing.

3. Ha CE, Bhagavan NV (2011) Essentials of medical biochemistry: With clinical cases. Academic Press USA.

4. Rabenstein DL (2002) Heparin and heparan sulfate: structure and function. Nat Prod Rep 19(3): 312-331.

5. Esko JD (1991) Genetic analysis of proteoglycan structure, function and metabolism. Curr Opin CellBiol 3(5): 805-816.
6. Yayon A, Klagsbrun M, Esko JD, Leder P, Ornitz DM (1991) Cell surface, heparin-likemolecules are required for binding of basic fibroblast growth factor to its high affinity receptor. Cell 64(4): 841-848.

7. Sarrazin S, Lamanna WC, Esko JD (2011) Heparan sulfate proteoglycans. Cold Spring Harb.Perspect. Biol 3(7): a004952.

8. Edgren G, Havsmark B, Jönsson M, Fransson LA (1997) Glypican (heparan sulfateproteoglycan) is palmitoylated, deglycanated and reglycanated during recycling in skinfibroblasts.Glycobiology 7(1): 103-112.

9. Aldairi AF, Ogundipe OD, Pye DA (2018) Antiproliferative activity of glycosaminoglycan-likepolysaccharides derived from marine molluscs. Mar Drugs 16(2): 63.

10. Zhang D, Wang C, Wu H, Xie J, Du L, et al. (2013) Three sulphated polysaccharides isolated from the mucilage of mud snail,Bullacta exarata philippi: Characterization and antitumour activity. Food Chem 138(1): 306-314

11. Wlawick R, Roberts W, Dekker C (1959) Cyclization during phosphorylation of uridine and Cytidine. ProcChemSoc: 84.

12. Hearn BR, Shaw SJ, Myles DC (2007) 7.04 - Microtubule Targeting Agents. J. B. Taylor and D.J.B.T.-C. M. C. I. I. Triggle, (Eds,), Elsevier, Oxford, UK, pp. 81-110.

13. Han N (2018) Derivatives of Dolastatin 10 and Uses Thereof. Google Patents.

14. Osgood CL, Chuk MK, Theoret MR, Huang L, He K, et al. (2017) FDA approval summary: Eribulin for patients with unresectable or metastaticliposarcoma who have received a prior anthracyclinecontaining regimen. Clin Cancer Res 23(21):6384-6389.

15. Avendaño C, Menéndez JC (2008) Chapter 10-Other Approaches to Targeted Therapy. C.Avendaño, J. C. B. T.-M. C. of A. D. Menéndez, (Eds,), Elsevier, Amsterdam, Netherlands, pp. 307-349.

16. Ning C, Wang HD, Gao R, Chang YC, Hu F, et al. (2018) Marine-derived protein kinase inhibitors for neuroinflammatory diseases. Biomed. Eng Online 17(1): 46.

17. Nobili S, Lippi D, Witort E, Donnini M, Bausi L, et al. (2009) Natural compounds for cancer treatment and prevention. Pharmacol Res 59(6): 365-378. 
18. Cesaretti M, Luppi E, Maccari F, Volpi N (2004) Isolation and characterization of a heparin withhigh anticoagulant activity from the clam Tapes phylippinarum: Evidence for the presence of a high content of antithrombin III binding site. Glycobiology 14(12): 1275-1284.

19. Amornrut C, Toida T, Imanari T, Woo ER, Park H, et al. (1999) A new sulfated $\beta$-galactan from clams with anti-HIV activity. Carbohydr Res 321(1-2): 121-127.

20. Liao N, Chen S, Ye X, Zhong J, Wu N, et al. (2013) Antioxidant and antitumor activity of a polysaccharide from freshwater clam,Corbicula fluminea. Food Funct 4(4): 539-548.

21. Khurshid C, Pye DA (2018) Isolation and Composition Analysis of Bioactive Glycosaminoglycansfrom Whelk. Mar Drugs 16(5)

22. Brito AS, Cavalcante RS, Palhares LC, Hughes AJ, Andrade GP, et al. (2014) A non-hemorrhagic hybrid heparin/heparan sulfate with anticoagulant Potential. Carbohydr Polym 99: 372-378.

23. Kim YS, Jo YY, Chang IM, Toida T, ParkY, et al. (1996) A new glycosaminoglycanfrom the giant African snail Achatina fulica. J Biol Chem 271(20): 11750-11755.

24. Santos JC, Juliana MF Mesquita, Celso LR Belmiro, Carolina BM Da Silveira, Christian Viskov, et al. (2007) Isolation and characterization of a heparin with low antithrombin activity fromthe body of Styela plicata (Chordata-Tunicata). Distinct effects on venous and arterial models ofthrombosis. Thromb Res 121(2): 213-223.

25. Gomes AM, Kozlowski EO, Pomin VH, De Barros CM, Zaganeli JL, et al. (2010) Unique extracellular matrix heparan sulfate from the bivalve Nodipecten nodosus (Linnaeus,1758) safely inhibits arterial thrombosis after photochemically induced endothelial lesion. J Biol Chem 285(10): $7312-7323$

26. Kanchana S, Arumugam M, Giji S, Balasubramanian T (2013) Isolation, characterization andantioxidant activity of hyaluronic acid from marine bivalve mollusc Amussium pleuronectus(Linnaeus, 1758). BioactCarbohydrates DietFibre 2(1): 1-7

27. Sadhasivam G, Muthuvel A, Pachaiyappan A, Thangavel B (2013) Isolation and characterizationof hyaluronic acid from the liver of marine stingray Aetobatus narinari. Int J Biol Macromol 54(1): 84-89.

28. Volpi N, Maccari F (2009) Structural characterization and antithrombin activity of dermatansulfate purified from marine clam Scapharca inaequivalvis. Glycobiology 19(4): 356-367.

29. Volpi N, F Maccari (2003) Purification and characterization of hyaluronic acid from the molluscbivalve Mytilus galloprovincialis. Biochimie 85(6): 619-0625.

30. Maccari F, Galeotti F, Volpi N (2015) Isolation and structural characterization of chondroitinsulfate from bony fishes. CarbohydrPolym 129: 143-147.

31. Kaczmarek B, Sionkowska A, Osyczka AM (2017) Collagen-based scaffolds enriched withglycosaminoglycans isolated from skin of Salmo salar fish. Polym Test 62: 132-136.

32. Higashi K, Yoshiki Takeuchi, Ann Mukuno, Hideyuki Tomitori, Masaki Miya, et al. (2015) Composition of glycosaminoglycans in elasmobranchs including several deepseasharks: Identification of chondroitin/ dermatan sulfate from the dried fins of Isurus oxyrinchusand Prionace glauca. PLoS One 10(3): 1-15.

33. Higashi K, Okamoto Y, Mukuno A, Wakai J, Hosoyama S, et al. (2015) Functional chondroitin sulfate from Enteroctopus dofleini containing a 3-0-sulfoglucuronic acid residue. CarbohydrPolym 134: 557-565.

34. Okamoto Y, Higashi K, Linhardt RJ, Toida T (2018) Comprehensive analysis ofglycosaminoglycans from the edible shellfish CarbohydrPolym 184: 269-276.
35. Higashi K, Toida T (2017) Isolation of Keratan Sulfate Disaccharidebranched Chondroitin SulfateE from Mactra chinensis. Bio-Protocol $7(15):$ 5-9.

36. Vijayabaskar P, Balasubramanian T, Somasundaram ST (2008) Lowmolecular weight molluscanglycosaminoglycan from bivalve Katelysia opima (Gmelin). Methods Find Exp Clin Pharmacol 30(3): 175-180.

37. Periyasamy N, Murugan S, Bharadhirajan P (2013) Anticoagulant activity of marine gastropodsbabylonia spirata lin, 1758 and phalium glaucum lin, 1758 collected from cuddalore, southeast costof INDIA. Int J Pharm Pharm Sci 5(4): 117-121.

38. Kates M, Work TS, Work E (1972) Techniques of lipidology: isolation, analysis and identification oflipids, North-Holland Amsterdam, 350.

39. Kariya Y, Watabe S, Ochiai Y, Hashimoto K, Murata K (1990) glycos amino glycan from the body wall of the sea cucumber stichopus japonicus 95(2): 387-392.

40. Vincent Gloaguen, Véronique Brudieux, Brigitte Closs $¥$ Aline Barbat, Pierre Krausz (2010) Structural characterization and cytotoxic properties of an apiose-rich pecticpolysaccharide obtained from the cell wall of the marine phanerogam Zostera marina. JNatProd 73(6): 10871092.

41. Sham MM, Suhaityazmi N (2016) Blue-spotted stingray: A promising source of beneficial glycosaminoglycans (GAGS). Int J Appl Chem 12(4): 795-802.

42. LFB TA in P Silva (2006) Isolation and Purification of Chondroitin Sulfate, in Chondroitin Sulfate: Structure, Role and Pharmacological Activity, Academic Press, 53: 21-31.

43. Chakravarthy PK, Acharya S (2012) Efficacy of extrinsic stain removal by novel dentifrice containing papain and bromelain extracts. J Young Pharm 4(4): 245-249.

44. Ben Mansour M, Majdoub H, Bataille I, Roudesli MS, Hassine M, et al. (2009) Polysaccharides from the skin of the ray Raja radula. Partial characterization and anticoagulant activity. Thromb Res 123(4): 671678.

45. Doucet D, Otter DE, Gauthier SF, Foegeding EA (2003) Enzyme-induced gelation of extensively hydrolyzed whey proteins by Alcalase: peptide identification and determination ofenzyme specificity. J Agric Food Chem 51(21): 6300-6308.

46. Del M Yust M, Justo Pedroche, Cristina Megías, J Girón-Calle (2003) Improvement of protein extraction from sunflower meal by hydrolysis withalcalase. Grasas y aceites 54(4): 419-423.

47. Panagos CG, Thomson D, Moss C, Bavington CD, Ólafsson HG (2014) Characterisation of hyaluronic acid and chondroitin/dermatan sulfate from the lumpsucker fish,C. lumpus. Carbohydr. Polym 106(1): 25-33.

48. Pan Y, Wang P, Zhang F, Yu Y, Zhang X, et al. (2018) Glycosaminoglycans from fish swim bladder: isolation, structural characterization and bioactive potential. Glycocon jJ 35(1): 87-94.

49. Onishi A, St Ange K, Dordick JS, Linhardt RJ (2016) Heparin and anticoagulation. Front Biosci(Landmark Ed) 21: 1372-1392.

50. Biotech AP (1998) Gel filtration: principles and methods. Uppsala, Sweden; Piscataway, NJ Amersham Pharmacia Biotech.

51. Brito AS, Arimatéia DS, Souza LR, Lima MA, Santos VO, et al. (2008) Anti-inflammatory properties of a heparin-like glycosaminoglycan with reducedanti-coagulant activity isolated from a marine shrimp. Bioorganic Med Chem 16(21): 9588-9595. 
ISSN: $2574-1241$

DOI: $10.26717 /$ BJSTR.2020.27.004531

Abdullah Faisal Aldairi. Biomed J Sci \& Tech Res

(c) (P) This work is licensed under Creative Commons Attribution 4.0 License

Submission Link: https://biomedres.us/submit-manuscript.php

$\begin{array}{ll}\text { BIOMEDICAL } & \text { Assets of Publishing with us } \\ \text { RESEARCHES } & \text { - Global archiving of articles } \\ \text { - Immediate, unrestricted online access } \\ \text { - Rigorous Peer Review Process } \\ \text { https://biomedres.us/ }\end{array}$

